\title{
Pengaruh Pemberian Pupuk Organik Guano terhadap Pertumbuhan dan Hasil Tanaman Mentimun pada Lahan Rawa Lebak
}

\section{(Guano Organic Fertilizer Giving Effect to Cucumber Growth and Yield on Lebak Wetlands)}

\author{
Nurul Hasanah" ${ }^{1)}$, Mahdiannoor ${ }^{2)}$ \&Nurul Istiqomah ${ }^{3)}$ \\ Program Studi Agroteknologi, Sekolah Tinggi Ilmu Pertanian Amuntai \\ ${ }^{1)}$ nurulhasanah@gmail.com \\ ${ }^{2)}$ mahdi_186@yahoo.com \\ ${ }^{3)}$ qoqom_81@yahoo.co.id
}

\begin{abstract}
ABSTRAK
Lahan rawa lebak umumnya dapat dimanfaatkan sebagai lahan budidaya sayuran dengan penanganan yang tepat. Tanah rawa lebak mempunyai masalah sifat kimia yang cukup komplek. Pemberian bahan organik salah satu cara memperbaiki beberapa sifat kimia tanah. Penelitian ini bertujuan (i) mengetahui pengaruh pemberian pupuk organik guano terhadap pertumbuhan dan hasil tanaman mentimun pada lahan rawa lebak (ii) mendapatkan dosis terbaik pupuk organik guano terhadap pertumbuhan dan hasil tanaman mentimun pada lahan rawa lebak. Penelitian ini dilaksanakan di Desa Pasar Senin Kecamatan Amuntai Tengah Kabupaten Hulu Sungai Utara dari bulan Mei - Juli 2012. Penelitian ini menggunakan Rancangan Acak Kelompok (RAK), dengan 5 perlakuan dan 5 ulangan, sehingga terdapat 25 satuan, dan setiap perlakuan ada 4 tanaman. Faktor yang di uji adalah dosis pupuk organik guano yaitu $g_{0}=0 \mathrm{~kg}$.petak ${ }^{-1}, g_{2}=0,5 \mathrm{~kg}$.petak ${ }^{-1}, g_{3}=0,1 \mathrm{~kg} \cdot$ petak $^{-1}, g_{4}=1,5 \mathrm{~kg} \cdot$ petak $\mathrm{k}^{-1}$ dan $g_{5}=$ 2 kg.petak ${ }^{-1}$. Hasil penelitian ini menunjukkan bahwa perlakuan pemberian dosis pupuk organik guano yang berpengaruh sangat nyata pada tinggi tanaman umur 7, 14 dan 21 HST, jumlah daun umur 7, 14 dan 21 HST, jumlah buah, bobot buah pertanaman dan panjang buah. Dosis terbaik pupuk organik guano yaitu 10 t.hal $\mathrm{h}^{-1}$ setara dengan 1 kg.petak ${ }^{-1}\left(g_{2}\right)$.
\end{abstract}

Kata kunci : Rawa, lebak, mentimun, pupuk, guano.

\section{ABSTRACT}

Lebak wetland can generally be used as vegetable cultivation land with proper handling. Lebak wetland land has a complex chemical problem. Giving organic material is one way to improve some soil chemical properties. The aim of this research is (i) to know the effect of guano organic fertilizer on the growth and yield of cucumber plants on lebak wetland (ii) to get the best dose of guano organic fertilizer on the growth and yield of cucumber plants on lebak wetland. The research was conducted in the Pasar Senin Village, Amuntai Tengah District, Hulu Sungai Utara Regency from May - July 2012. This study used a randomized block design (RBD), with 5 treatments and 5 replications, so there are 25 units, and each treatment there are 4 plants. Factor test in the guano organic fertilizer that $g_{0}=0 \mathrm{~kg} \cdot \mathrm{plot}^{-1}, \mathrm{~g}_{2}=0.5 \mathrm{~kg}$.plot ${ }^{1}, g_{3}=0.1 \mathrm{~kg} \cdot$ plot $^{-1}, g_{4}=1.5 \mathrm{~kg} \cdot \mathrm{plot}^{-1}$ and $g_{5}=2 \mathrm{~kg} \cdot \mathrm{plot}^{-1}$. Results of this study showed that treatment dosing guano organic fertilizer which was highly significant on plant height ages 7, 14 and 21 DAP, number of leaves aged 7, 14 and 21 DAP, number of fruits, fruit weight and length of the fruit. The best dose of guano organic fertilizer is 10 t.ha $\mathrm{a}^{-1}$ equivalent to $1 \mathrm{~kg}^{. \mathrm{plot}^{-1}}\left(\mathrm{~g}_{2}\right)$.

Keywords: Wetlands, lebak, cucumber, fertilizer, guano.

\section{PENDAHULUAN}

Mentimun, timun atau ketimun merupakan salah satu jenis sayuran dari famili Cucurbitales yang sudah populer diseluruh dunia. Menurut sejarahnya tanaman mentimun berasal dari benua Asia. Beberapa sumber literatur menyebutkan daerah asal tanaman mentimun adalan benua Asia Utara, tetapi sebagian lagi menduga berasal dari Asia Selatan. Para ahli tanaman memastikan daerah asal mentimun adalah India, tepatnya di lereng gunung Himalaya (Rukmana, 1994).

Di Kalimantan Selatan rata-rata hasil mentimun hanya $2,57 \mathrm{t} / \mathrm{ha}$ sedangkan rata - 
rata hasil tingkat nasional 9,26 t/ha (Sumpena, 2002 dalam Simatupang et. al, 2004). Pada tahun 2009 produksi mentimun di Hulu Sungai Utara 5,54 t. ha (BPS HSU, 2010).

Tanah rawa lebak ialah suatu bagian daratan, yang sepanjang tahunnya jenuh air atau tergenang air. Lahan ini sepanjang tahun atau selama waktu yang panjang dalam setahun selalu jenuh air (water logged) atau tergenang (Adhi e.t al. dalam Rafieq, 2004).

Berdasarkan hasil analisis Laboratorium Kimia, Fisika dan Biologi Tanah Fakultas Pertanian Unlam (2012), lahan rawa lebak di tempat penelitian yang akan digunakan sebagai lahan penelitian mengandung $\mathrm{pH}$ yang agak masam yaitu 5,59 $\mathrm{N}$ yang rendah yaitu $0,16 \%, \mathrm{P}$ yang tinggi yaitu 54,81 ppm, K yang rendah yaitu 10,86 ppm dan C-organik yang rendah yaitu 1,25 $\%$.

Tanah rawa lebak mempunyai kemasaman yang relatif tinggi ( $\mathrm{pH}$ rendah), kandungan $\mathrm{C}$-organik rendah, $\mathrm{P}$-total tinggi tetapi $\mathrm{P}$-tersedia rendah begitu juga $\mathrm{K}$ bisa ditukar rendah. Tinggi kandungan $\mathrm{Al}$ dan $\mathrm{Fe}$ tanah mengakibatkan tingginya kemasaman tanah, rendahnya ketersediaan $\mathrm{P}$ meskipun $\mathrm{P}$ total tanah begitu juga $\mathrm{K}$ dapat ditukar menjadi rendah. Pada kondisi tanah yang masam tentunya akan mengakibatkan firmentasi $\mathrm{P}$ oleh $\mathrm{Fe}$ dan $\mathrm{Al}$ sehingga unsur hara $\mathrm{P}$ tidak tersedia bagi tanaman. Dilain pihak karena $\mathrm{K}$ merupakan unsur hara yang sifatnya mobil sehingga mudah tercuci kelapisan tanah yang lebih dalam yang mengakibatkan kesediaannya juga rendah. Pemberian bahan organik salah satu cara memperbaiki beberapa sifat kimia tanah (Simatupang et. al., 2006).

Bahan organik yang telah mengalami dekomposisi bermanfaat terhadap pertumbuhan tanaman. Tanaman memerlukan unsur hara yang cukup dan tersedia bagi pertumbuhan dan perkembangan untuk menghasilkan produksi yang maksimal. Pemberian bahan organik berupa pupuk guano sangat membantu dalam memperbaiki tingkat kesuburan tanah, dimana kandungan unsur $\mathrm{N}, \mathrm{P}, \mathrm{K}$ dan $\mathrm{Ca}$ sangat tinggi sehingga baik untuk proses pertumbuhan tanaman. Nitrogen sangat mendukung pertumbuhan tanaman yang cepat, fosfor $(\mathrm{P})$ merangsang pertumbuhan akar dan pembungaan, kalium (K) mendukung kekuatan batang tanaman, sedangkan $\mathrm{Ca}$ akan mengubah atau menggeser kedudukan ion $\mathrm{H}+$ pada permukaan koloid sehingga menetralisir kemasaman tanah (Sarief, 1986 dalam Simatupang et. al., 2006).

Kandungan unsur $\mathrm{N}$ dalam guano jauh lebih tinggi dari pada yang terdapat dalam pupuk kandang, limbah pertanian, maupun sampah rumah tangga (Suwarno dan Idris, 2007). Berdasarkan hasil analisis Laboratorium Kimia, Fisika dan Biologi Tanah Fakultas Pertanian Unlam (2012), kandungan pupuk organik guano yang akan digunakan dalam penelitian ini adalah $\mathrm{N}$ yang sangat tinggi yaitu $1,67 \%, \mathrm{P}$ yang sangat tinggi yaitu $8,64 \mathrm{ppm}, \mathrm{K}$ yang sedang yaitu $0,21 \mathrm{ppm}, \mathrm{C}$-organik yang sangat tinggi yaitu $8,62 \%$ dan $\mathrm{pH}$ yang sangat tinggi yaitu 5,50 $\%$.

$$
\text { Penelitian ini bertujuan }
$$

mengetahui pengaruh pemberian pupuk organik guano terhadap pertumbuhan dan hasil tanaman mentimun pada lahan rawa lebak (ii) mendapatkan dosis terbaik pupuk organik guano terhadap pertumbuhan dan hasil tanaman mentimun pada lahan rawa lebak.

\section{METODE PENELITIAN}

Percobaan ini dilaksanakan di Desa Pasar Senin Kecamatan Amuntai Tengah Kabupaten Hulu Sungai Utara, mulai bulan Mei - Juli 2012. Bahan dan alat yang digunakan adalah benih mentimun Varietas Hercules, media tanam, pupuk organik guano, turus/ajir, air dan pestisida alami. Alat-alat yang digunakan adalah cangkul, sekop, parang, alat pengukur, hand sprayer, gembor, alat tulis, tali dan alat dokumentasi.

Penelitian ini percobaan yang dilakukan dilapangan menggunakan Rancangan Acak Kelompok (RAK) faktor tunggal. Perlakuan dalam penelitian ini adalah pupuk organik guano $(\mathrm{G})$ yang terdiri dari 5 taraf yaitu : $\mathrm{g}_{0}=0 \mathrm{t}^{\mathrm{h}} \mathrm{ha}^{-1}=0 \mathrm{~kg}$.petak 
Nurul Hasanah, Mahdiannoor \& Nurul Istiqomah, Pengaruh pemberian pupuk organik..

${ }^{1}, g_{1}=5$ t.ha ${ }^{-1}=0,5 \mathrm{~kg} \cdot$ petak $^{-1}, \mathrm{~g}_{2}=10$ t.ha

$1=1,0 \mathrm{~kg} \cdot$ petak $^{-1}, \mathrm{~g}_{3}=15 \mathrm{t} \cdot \mathrm{ha}^{-1}=1,5$ kg.petak ${ }^{-1}, \mathrm{~g}_{4}=20$ t.ha ${ }^{-1}=2$ kg.petak ${ }^{-1}$. Setiap perlakuan diulang $5 \mathrm{kali}$, sehingga terdapat 25 satuan percobaan terdiri dari 4 sampel tanaman.

Pelaksanaan percobaan meliputi persiapan, pelaksanaan pembersihan lahan, pengolahan tanah, pemupukan, penanaman, pemeliharaan, panen. Peubah pengamatan yang di ukur pada percobaan ini adalah tinggi tanaman. jumlah daun pertanaman, jumlah buah pertanaman, bobot buah pertanaman, panjang buah pertanaman.

Setelah data terkumpul, maka terlebih dahulu dilakukan uji kehomogenan ragam Bartlett. Apabila data homogen untuk mengetahui ada tidaknya pengaruh perlakuan pemberian pupuk guano terhadap pertumbuhan dan hasil tanaman mentimun, maka dilakukan uji - F pada taraf nyata $5 \%$ dan $1 \%$. Apabila uji - $\mathrm{F}$ menunjukkan pengaruh nyata atau sangat nyata, pengujian dilanjutkan dengan Uji Beda Nilai Tengah perlakuan dengan menggunakan Uji DMRT pada taraf nyata $5 \%$.

\section{HASIL DAN PEMBAHASAN}

\section{Hasil}

\section{Tinggi Tanaman}

Berdasarkan hasil analisis ragam peubah data yang diamati menunjukkan bahwa perlakuan pemberian pupuk guano berpengaruh sangat nyata terhadap tinggi tanaman pada umur 7, 14, dan 21 HST. Ratarata tinggi tanaman umur 7, 14, dan $21 \mathrm{HST}$ disajikan pada Tabel 1.

Tabel 1. Hasil uji beda rata-rata tinggi tanaman terhadap pemberian pupuk guano

\begin{tabular}{cccc}
\hline Dosis pupuk & \multicolumn{3}{c}{ Rata-rata tinggi tanaman $(\mathrm{cm})$} \\
\cline { 2 - 4 } organik guano & $7 \mathrm{HST}$ & $14 \mathrm{HST}$ & $21 \mathrm{HST}$ \\
\hline $\mathrm{g}_{0}$ & $7,20^{\mathrm{a}}$ & $16,11^{\mathrm{a}}$ & $34,40^{\mathrm{a}}$ \\
$\mathrm{g}_{1}$ & $7,80^{\mathrm{ab}}$ & $17,88^{\mathrm{ab}}$ & $36,25^{\mathrm{ab}}$ \\
$\mathrm{g}_{2}$ & $8,30^{\mathrm{bc}}$ & $19,95^{\mathrm{bc}}$ & $44,87^{\mathrm{bc}}$ \\
$\mathrm{g}_{3}$ & $9,00^{\mathrm{c}}$ & $21,92^{\mathrm{cd}}$ & $54,10^{\mathrm{c}}$ \\
$\mathrm{g}_{4}$ & $9,30^{\mathrm{c}}$ & $22,96^{\mathrm{d}}$ & $53,90^{\mathrm{c}}$ \\
\hline
\end{tabular}

Keterangan : Nilai rata-rata yang diikuti huruf yang berbeda pada kolom yang sama menunjukkan perlakuan tersebut berbeda berdasarkan uji DMRT pada taraf $5 \%$

Dari Tabel 1 terlihat bahwa pada umur 7 HST, perlakuan pemberian pupuk guano pada dosis 20 ton.ha $^{-1} \quad\left(\mathrm{~g}_{4}\right)$ menunjukkan rata-rata tinggi tanaman tertinggi yaitu $9,30 \mathrm{~cm}$ yang tidak berbeda dengan $\mathrm{g}_{2}$ dan $\mathrm{g}_{3}$, tetapi berbeda dengan $\mathrm{g}_{0}$ dan $\mathrm{g}_{1}$. Perlakuan terbaik pada umur 7 HST adalah g2. Pada umur 14 HST, dosis $g_{4}$ menunjukkan rata-rata tinggi tanaman tertinggi yaitu $22,96 \mathrm{~cm}$ yang tidak berbeda dengan $g_{3}$, tetapi berbeda dengan $g_{0}, g_{1}$, dan $\mathrm{g}_{2}$. Perlakuan terbaik pada umur 14 HST adalah $\mathrm{g}_{3}$. Pada umur $21 \mathrm{HST}$, dosis $\mathrm{g}_{4}$ menunjukkan rata-rata tinggi tanaman tertinggi yaitu $53,90 \mathrm{~cm}$ yang tidak berbeda dengan $g_{2}$ dan $g_{3}$, tetapi berbeda dengan $g_{0}$ dan $\mathrm{g}_{1}$. Perlakuan terbaik umur 21 HST adalah $g_{2}$.

\section{Jumlah Daun Pertanaman}

Berdasarkan hasil analisis ragam peubah data yang diamati menunjukkan bahwa perlakuan pemberian pupuk guano berpengaruh sangat nyata terhadap jumlah daun pertanaman umur 7, 14, dan 21 HST. Rata-rata jumlah daun pertanaman umur 7, 14, dan 21 HST disajikan pada Tabel 2.

Tabel 2. Hasil uji beda rata-rata jumlah daun terhadap pemberian pupuk guano 


\begin{tabular}{cccc}
\hline Dosis pupuk & \multicolumn{3}{c}{ Rata-rata jumlah daun (helai) } \\
\cline { 2 - 4 } organik guano & $7 \mathrm{HST}$ & $14 \mathrm{HST}$ & $21 \mathrm{HST}$ \\
\hline $\mathrm{g}_{0}$ & $2,15^{\mathrm{a}}$ & $4,25^{\mathrm{a}}$ & $7,75^{\mathrm{a}}$ \\
$\mathrm{g}_{1}$ & $2,45^{\mathrm{b}}$ & $4,55^{\mathrm{ab}}$ & $7,95^{\mathrm{a}}$ \\
$\mathrm{g}_{2}$ & $2,60^{\mathrm{b}}$ & $4,85^{\mathrm{bc}}$ & $9,45^{\mathrm{ab}}$ \\
$\mathrm{g}_{3}$ & $2,75^{\mathrm{bc}}$ & $5,05^{\mathrm{c}}$ & $11,00^{\mathrm{b}}$ \\
$\mathrm{g}_{4}$ & $2,95^{\mathrm{c}}$ & $5,10^{\mathrm{c}}$ & $10,60^{\mathrm{b}}$ \\
\hline
\end{tabular}

Keterangan : Nilai rata-rata yang diikuti huruf yang berbeda pada kolom yang sama menunjukkan perlakuan tersebut berbeda nyata berdasarkan uji DMRT pada taraf $5 \%$

Dari Tabel 2 terlihat bahwa pada umur $7 \mathrm{HST}$, perlakuan pemberian pupuk guano pada dosis 20 ton.ha $^{-1} \quad\left(\mathrm{~g}_{4}\right)$ menunjukkan rata-rata jumlah daun terbanyak yaitu 2,95 helai yang tidak berbeda dengan $\mathrm{g}_{3}$, tetapi berbeda nyata dengan $\mathrm{g}_{0}, \mathrm{~g}_{1}$ dan $g_{2}$. Perlakuan terbaik umur 7 HST adalah $\mathrm{g}_{3}$. Pada umur $14 \mathrm{HST}$, dosis $\mathrm{g}_{4}$ menunjukkan rata-rata jumlah daun terbanyak yaitu 5,10 helai yang tidak berbeda dengan $\mathrm{g}_{2}$ dan $\mathrm{g}_{3}$, tetapi berbeda nyata dengan $\mathrm{g}_{0}$ dan $\mathrm{g}_{1}$. Pada umur $21 \mathrm{HST}$, dosis $\mathrm{g}_{4}$ menunjukkan ratarata terbanyak yaitu 10,60 helai yang tidak berbeda dengan $\mathrm{g}_{2}$ dan $\mathrm{g}_{3}$, tetapi berbeda nyata dengan $\mathrm{g}_{0}$ dan $\mathrm{g}_{1}$. Sebagai perlakuan terbaik umur 14 dan 21 HST adalah perlakuan $\mathrm{g}_{2}$.

\section{Jumlah Buah Pertanaman}

Berdasarkan hasil analisis ragam peubah data yang diamati menunjukkan bahwa perlakuan pemberian pupuk guano berpengaruh nyata terhadap jumlah buah pertanaman. Rata-rata jumlah buah pertanaman disajikan pada Tabel 3.

Tabel 3. Hasil uji beda rata-rata jumlah buah terhadap pemberian pupuk guano

\begin{tabular}{cc}
\hline Dosis pupuk organik guano & Rata-rata jumlah buah (buah) \\
\hline $\mathrm{g}_{0}$ & $1,95^{\mathrm{a}}$ \\
$\mathrm{g}_{1}$ & $1,95^{\mathrm{a}}$ \\
$\mathrm{g}_{2}$ & $2,90^{\mathrm{ab}}$ \\
$\mathrm{g}_{3}$ & $3,65^{\mathrm{b}}$ \\
$\mathrm{g}_{4}$ & $3,10^{\mathrm{ab}}$ \\
\hline
\end{tabular}

Keterangan : Nilai rata-rata yang diikuti huruf yang berbeda pada kolom yang sama menunjukkan perlakuan tersebut berbeda nyata berdasarkan uji DMRT pada taraf $5 \%$

Dari Tabel 3 terlihat bahwa perlakuan pemberian pupuk guano pada dosis 15 ton.ha ${ }^{-}$ ${ }_{1}\left(\mathrm{~g}_{3}\right)$ menunjukkan rata-rata jumlah buah pertanaman yang terbanyak yaitu 3,65 buah yang tidak berbeda dengan $\mathrm{g}_{2}$ dan $\mathrm{g}_{4}$, tetapi berbeda dengan $\mathrm{g}_{0}$ dan $\mathrm{g}_{1}$. Sebagai perlakuan terbaik adalah $\mathrm{g}_{2}$.

\section{Bobot Buah Pertanaman}

Berdasarkan hasil analisis ragam peubah data yang diamati menunjukkan bahwa perlakuan pemberian pupuk guano berpengaruh nyata terhadap bobot buah pertanaman. Rata-rata bobot buah pertanaman disajikan pada Tabel 4.

Tabel 4. Hasil uji beda rata-rata bobot buah terhadap pemberian pupuk guano 
Nurul Hasanah, Mahdiannoor \& Nurul Istiqomah, Pengaruh pemberian pupuk organik..

\begin{tabular}{cc}
\hline Dosis pupuk organik guano & Rata-rata bobot buah $(\mathrm{kg})$ \\
\hline $\mathrm{g}_{0}$ & $0,30^{\mathrm{a}}$ \\
$\mathrm{g}_{1}$ & $0,30^{\mathrm{a}}$ \\
$\mathrm{g}_{2}$ & $0,31^{\mathrm{ab}}$ \\
$\mathrm{g}_{3}$ & $0,33^{\mathrm{b}}$ \\
$\mathrm{g}_{4}$ & $0,33^{\mathrm{b}}$
\end{tabular}

Keterangan : Nilai rata-rata yang diikuti huruf yang berbeda pada kolom yang sama menunjukkan perlakuan tersebut berbeda nyata berdasarkan uji DMRT pada taraf $5 \%$

Dari Tabel 4 terlihat bahwa perlakuan pemberian pupuk guano pada dosis 20 ton.ha ${ }^{-}$ 1 ( $\left.\mathrm{g}_{4}\right)$ menunjukkan rata-rata bobot buah pertanaman yang tertinggi yaitu $0,33 \mathrm{~kg}$ yang tidak berbeda dengan $\mathrm{g}_{2}$ dan $\mathrm{g}_{3}$, tetapi berbeda dengan $g_{0}$ dan $g_{1}$. Sebagai perlakuan terbaik adalah $\mathrm{g}_{2}$.

\section{Panjang Buah Pertanaman}

Berdasarkan hasil analisis ragam peubah data yang diamati menunjukkan bahwa perlakuan pemberian pupuk guano berpengaruh nyata terhadap panjang buah pertanaman. Rata-rata panjang buah pertanaman disajikan pada Tabel 5.

Tabel 5. Hasil uji beda rata-rata panjang buah terhadap pemberian pupuk guano

\begin{tabular}{cc}
\hline Dosis pupuk organik guano & Rata-rata panjang buah $(\mathrm{cm})$ \\
\hline $\mathrm{g}_{0}$ & $22,38^{\mathrm{a}}$ \\
$\mathrm{g}_{1}$ & $22,20^{\mathrm{a}}$ \\
$\mathrm{g}_{2}$ & $22,82^{\mathrm{ab}}$ \\
$\mathrm{g}_{3}$ & $23,71^{\mathrm{b}}$ \\
$\mathrm{g}_{4}$ & $23,34^{\mathrm{b}}$ \\
\hline
\end{tabular}

Keterangan : Nilai rata-rata yang diikuti huruf yang berbeda pada kolom yang sama menunjukkan perlakuan tersebut berbeda nyata berdasarkan uji DMRT pada taraf $5 \%$

Dari Tabel 5 terlihat bahwa perlakuan pemberian pupuk guano pada dosis 15 ton.ha ${ }^{-}$ ${ }^{1}\left(\mathrm{~g}_{3}\right)$ menunjukkan rata-rata panjang buah pertanaman yang terpanjang yaitu $23,71 \mathrm{~cm}$ yang tidak berbeda dengan $\mathrm{g}_{2}$ dan $\mathrm{g}_{4}$, tetapi berbeda dengan $\mathrm{g}_{0}$ dan $\mathrm{g}_{1}$. Sebagai perlakuan terbaik adalah $\mathrm{g}_{2}$.

\section{Pembahasan}

\section{Tinggi Tanaman}

Berdasarkan hasil analisis ragam peubah data yang diamati, pemberian pupuk guano berpengaruh sangat nyata terhadap tinggi tanaman mentimun pada umur 7, 14, dan 21 HST. Hal ini menunjukan bahwa pemberian pupuk guano dapat memenuhi kebutuhan hara tanaman mentimun, terutama unsur $\mathrm{N}$ yang sangat dibutuhkan dalam jumlah yang relatif besar pada tahap pertumbuhannya.

Berdasarkan hasil analisis kimia, pupuk guano mengandung unsur $\mathrm{N}$ dan $\mathrm{P}$ yang sangat tinggi (Laboratorium Kimia, Fisika dan Biologi Tanah, 2012). Tingginya kandungan unsur $\mathrm{N}$ pada pupuk yang digunakan ini dapat membantu memenuhi kekurangan unsur $\mathrm{N}$ dalam tanah. Menurut Novizan (2002), unsur $\mathrm{N}$ ini sangat dibutuhkan tanaman pada tahap pertumbuhan vegetatif seperti pembentukan tunas dan perkembangan batang. Sumber utama N berasal dari gas $\mathrm{N}_{2}$ dari atmosfir. Kadar gas nitrogen di atmosfir bumi berkisar $79 \%$. Walaupun jumlahnya sangat besar, tetapi nitrogen tersebut belum dapat dimanfaatkan oleh tanaman, kecuali telah menjadi bentuk yang tersedia (Rosmarkam dan Yuwono, 2002). Menurut Purwadi (2011), agar bisa 
dimanfaatkan oleh tanaman maka unsur $\mathrm{N}$ yang ada di udara tersebut terlebih dahulu harus berfiksasi dengan unsur $\mathrm{H}$ ataupun oksigen dan air. Selain itu, unsur N dapat ditambat oleh organisme mikro seperti Rhizhobium yang ada di bintil akar tanaman kacang-kacangan dan juga dapat difiksasi oleh bakteri dalam tanah yang menambat unsur $\mathrm{N}$ di udara menjadi unsur yang tersedia bagi tanaman.

Nitrat yang dihasilkan oleh fiksasi biologis digunakan oleh produsen (tumbuhan) diubah menjadi molekul protein, kemudian tumbuhan dikonsumsi oleh hewan. Selanjutnya jika tumbuhan dan hewan mati, pengurai merombaknya menjadi amonia $\left(\mathrm{NH}_{3}\right)$ dan amonium $\left(\mathrm{NH}_{4}^{+}\right)$, proses ini disebut dengan ammonifikasi. Bakteri Nitrosomonas mengubah amonia dan amonium tersebut menjadi nitrit $\left(\mathrm{NO}_{2}{ }^{-}\right)$, kemudian oleh bakteri Nitrobacter diubah lagi menjadi nitrat $\left(\mathrm{NO}_{3}{ }^{-}\right)$, nitrat inilah yang akan diserap oleh tumbuhan, proses ini disebut dengan nitrifikasi (Rosmarkam dan Yuwono, 2002).

Menurut Novizan (2002), prosesproses tersebut hanya terjadi secara optimal di bawah temperatur hangat $\left(30^{\circ} \mathrm{C}\right)$, oksigen dan kelembaban yang cukup serta $\mathrm{pH}$ tanah yang netral. Nitrogen yang ada dalam tanah dapat hilang karena terjadinya penguapan, pencucian oleh air atau terbawa bersama tanaman pada saat panen. Tanah yang sangat basah atau sangat padat bisa menyebabkan kondisi anaerob (tidak terdapat cukup oksigen dalam tanah). Akibatnya terjadi reaksi yang mengubah nitrat menjadi gas nitrogen (reaksi denitrifikasi).

Pencucian nitrat sering terjadi pada tanah berpasir atau tanah yang sangat gembur. Saat pencucian terjadi, air memindahkan nitrat menuju lapisan bawah daerah perakaran. Erosi pada permukaan tanah akan menghanyutkan nitrogen ke sungai yang akhirnya bermuara ke laut. Selanjutnya akan terjadi proses pengembalian nitrogen ke tanah (Novizan, 2002).

Pemberian pupuk guano pada berbagai taraf dosis memberikan pengaruh sangat nyata terhadap pengamatan tinggi tanaman juga dikarenakan pupuk guano yang diberikan 2 minggu sebelum tanam pada tanah sudah mengalami proses dekomposisi, sehingga unsur hara menjadi tersedia bagi tanaman. Meningkatnya ketersediaan unsur $\mathrm{N}$ dalam tanah ini merangsang pembentukan tunas dan perkembangan batang tanaman (Novizan 2002).

Unsur hara $\mathrm{P}$ pada tanah sangat tinggi, $\mathrm{P}$ merupakan sumber penting bagi tanaman, didalam tanah kedudukan $\mathrm{P}$ sangat stabil karena tidak mudah larut dan terbawa air. Ketersediaan unsur $\mathrm{P}$ dalam tanah sangat dipengaruhi oleh $\mathrm{pH}$ tanah. Pada $\mathrm{pH}$ rendah ion $\mathrm{P}$ membentuk senyawa yang tidak larut dengan besi dan aluminium. Pada $\mathrm{pH}$ tinggi terikat sebagai senyawa kalsium, dalam penelitian terdapat $\mathrm{pH}$ tanah yang sangat tinggi sehingga dapat digunakan tanaman (Winawanti, 2011).

Ketersediaan unsur $\mathrm{P}$ yang tinggi dalam larutan tanah juga ikut berperan, unsur $P$ berfungsi untuk merangsang perkembangan akar tanaman, sehingga akar tanaman berkembang lebih luas. Hal ini menyebabkan akar tanaman mampu menyerap unsur hara dalam tanah secara optimal. Maka kontak secara difusi antar akar tanaman dan unsur hara dalam tanah menjadi lebih besar, sehingga lebih banyak unsur hara yang diserap oleh tanaman (Kaya, 2009).

Fosfor terdapat di alam dalam bentuk ion fosfat, ion fosfat banyak terdapat dalam bebatuan, adanya peristiwa erosi dan pelapukan menyebabkan fosfat terbawa menuju sungai hingga laut dan membentuk sedimen. Adanya pergerakan dasar bumi menyebabkan sedimen yang mengandung fosfat muncul ke pernukaan. Ion fosfat dapat memasuki air tanah sehingga tumbuhan dapat mengambil fosfat yang terlarut melalui absorbsi yang dilakukan oleh akar. Hewan mendapatkan fosfat dari tumbuhan yang dimakannya kemudian mengeluarkan fosfat melalui urin dan feses. Bakteri dan jamur mengurai bahan-bahan anorganik di dalam tanah lalu melepaskan fosfor yang bisa diambil oleh tumbuhan (Veanty, 2011).

\section{Jumlah Daun Pertanaman}


Nurul Hasanah, Mahdiannoor \& Nurul Istiqomah, Pengaruh pemberian pupuk organik..

Berdasarkan hasil analisis ragam peubah data yang diamati, pemberian pupuk guano berpengaruh sangat nyata terhadap jumlah daun tanaman mentimun pada umur 7, 14, dan 21 HST. Hal ini menunjukkan bahwa pemberian pupuk guano dapat memenuhi kebutuhan hara tanaman mentimun, terutama unsur $\mathrm{N}$ yang sangat dibutuhkan dalam pembentukan tunas dan perkembangan daun.

Menurut Rosmarkam dan Yuwono (2002), nitrogen diserap tanaman dalam bentuk ion $\mathrm{NO}_{3}^{-}$atau $\mathrm{NH}_{4}^{+}$dari tanah. Ketersediaan unsur ini dalam tanah mengalami peningkatan karena pupuk guano yang diberikan pada tanah sudah terdekomposisi. Tanaman yang mendapat suplai nitrogen yang cukup maka pertumbuhannya menjadi lebih baik, daun berwarna hijau, dan tidak mudah rontok.

Menurut Isrun (2010), serapan N tanaman berkaitan dengan perkembangan akar tanaman dan ketersediaan $\mathrm{N}$ tanah. Perkembangan akar tanaman menyebabkan peningkatan kemampuan tanaman untuk menyerap unsur $\mathrm{N}$ dalam tanah yang pada gilirannya akan menunjang peningkatan perkembangan bagian atas tanaman, termasuk perkembangan daun.

Selain itu tanaman mentimun juga membutuhkan unsur $(\mathrm{P})$ karena fungsi fosfor dalam tanaman adalah untuk mempercepat pertumbuhan akar semai, mempercepat dan memperkuat pertumbuhan tanaman dewasa pada umumnya, meningkatkan produk bijibijian dan memperkuat tumbuh tanaman sehingga tidak muda rebah (Mulyani, 2002).

Kalium (K) juga berperan penting bagi tanaman mentimun, karena pungsi utamanya $\mathrm{K}$ adalah membantu pembentukan protein dan karbohidrat. Kalium pun berperan dalam memperkuat tubuh tanaman agar daun, bunga dan buah tidak mudah gugur. Yang tidak bisa dilupakan kalium merupakan sumber kekuatan bagi tanaman dalam menghadapi kekeringan dan penyakit (Marsono, 2007).

Untuk pertumbuhan yang optimal selama fase vegetatif ini juga diimbangi oleh ion-ion lain seperti adanya ion fosfat yang membantu sintesis asam nukleat, dan juga ketersediaan ion $\mathrm{K}^{+}$yang mengatur penyerapan nitrat untuk sintesis menjadi protein (Rosmarkam dan Yuwono, 2002).

\section{Jumlah Buah Pertanaman}

Berdasarkan hasil analisis ragam peubah data yang diamati, pemberian pupuk guano berpengaruh nyata terhadap jumlah buah pertanaman. Hal ini menunjukkan bahwa pemberian pupuk guano dapat memenuhi kebutuhan hara tanaman mentimun sampai pada fase generatif. terutama unsur $\mathrm{P}$ yang sangat dibutuhkan dalam pembentukan buah (Novizan, 2002).

Hasil analisis laboratorium menunjukkan pupuk guano mengandung unsur $\mathrm{P}$ yang sangat tinggi. Pemberian pupuk guano selain dapat melepaskan unsur P yang dikandungnya, juga dapat membentuk khelat. Soepardi (1983) dalam Utami dan Suci (2003) menyatakan bahwa adanya senyawa organik yang cukup memungkinkan terjadinya khelat yaitu senyawa organik yang berikatan dengan kation logam seperti besi $(\mathrm{Fe})$, Mangan (Mn), dan Aluminium (Al). Hal ini menyebabkan berkurangnya kadar kelarutan Fe dan Al dalam tanah, sehingga unsur $\mathrm{P}$ akan dilepaskan dari ikatan $\mathrm{Fe}$ dan $\mathrm{Al}$ ke dalam larutan tanah.

Pemberian bahan organik juga melepaskan ion $\mathrm{OH}^{-}$ke dalam larutan tanah Ion $\mathrm{Al}^{3+}$ dan $\mathrm{Fe}^{3+}$ akan bereaksi dengan $\mathrm{OH}^{-}$ membentuk senyawa $\mathrm{Al}(\mathrm{OH})_{3}$ dan $\mathrm{Fe}(\mathrm{OH})_{3}$ yang sukar larut dan tidak ada lagi kesempatan bagi $\mathrm{Al}$ dan $\mathrm{Fe}$ untuk bereaksi dengan fosfat. Akibatnya fosfat akan bebas dan tersedia dalam larutan tanah (Kaya, 2009). Meningkatnya ketersediaan unsur $P$ dalam tanah ini dapat mencukupi kebutuhan hara yang diperlukan tanaman untuk pembentukan buah.

Unsur hara lain seperti ammonium yang berasal dari nitrogen dapat meningkatkan penyerapan fosfor, sehingga dengan tercukupinya ketersediaan unsur $\mathrm{N}$ ini semakin meningkatkan respon tanaman terhadap pemupukan fosfor (Novizan, 2002).

Unsur $\mathrm{P}$ berfungsi untuk membentuk asam nukleat (DNA dan RNA), menyimpan serta memindahkan energi Arlenusin Tri Phosphat dan adonosin Di Phosphat, 
merangsang pembelahan sel, dan membantu proses asimilasi dan respirasi. Dalam hal ini unsur $\mathrm{P}$ berfungsi merangsang pembentukan biji, di dukung oleh unsur C-organik sangat tinggi terdapat pada pupuk organik goano yang dibutuhkan tanaman mentimun sebagai regulator (pengatur) dalam penyerapan unsur P (Novizan, 2002).

\section{Bobot Buah Pertanaman}

Berdasarkan hasil analisis ragam peubah data yang diamati, pemberian pupuk guano berpengaruh nyata terhadap bobot buah pertanaman. Hal ini menunjukkan bahwa pemberian pupuk guano dapat memenuhi kebutuhan hara tanaman mentimun sampai pada fase generatif, terutama unsur $\mathrm{K}$ yang juga sangat dibutuhkan dalam pembentukan buah (Novizan, 2002).

Pupuk guano mengandung unsur $\mathrm{K}$ dengan kriteria sedang, pupuk ini mampu memberikan tambahan unsur $\mathrm{K}$ pada tanahz Secara umum peran kalium berhubungan dengan proses metabolisme, seperti fotosíntesis dan respirasi, unsur kalium berperan dalam proses translokasi gula pada pembentukan pati dan protein. Selain itu unsur kalium juga dapat memperbaiki ukuran dan kualitas buah pada masa generatif. Unsur kalium ini dibutuhkan pada tanaman buah dan sayuran yang memproduksi karbohidrat dalam jumlah banyak. Tercukupinya unsur $\mathrm{K}$ pada masa ini menyebabkan ukuran buah menjadi lebih besar (Novizan, 2002).

Unsur $\mathrm{N}$ juga terlibat dalam hal ini, unsur $\mathrm{N}$ berfungsi untuk membentuk senyawa penting seperti klorofil yang sangat dibutuhkan dalam proses fotosintesis oleh tanaman. Hal ini membantu proses fotosintesis tanaman berjalan secara maksimal dan menghasilkan karbohidrat yang lebih banyak untuk disimpan pada buah (Novizan, 2002).

Pungsi dari $\mathrm{P}$ (fosfor) dalam tanaman mempercepat pertumbuhan akar semai, dapat mempercepat serta memperkuat pertumbuhan tanaman muda menjadi tanaman dewasa pada umumnya, dapat mempercepat pembungaan, pemasakan buah, biji atau gabah dan juga dapat meningkatkan produksi biji-bijian. Bahwa fosfor didalam tanah dapat digolongkan dalam 2 bentuk yaitu bentuk organis, dan bentuk anorganis. Di dalam tanah fungsi $\mathrm{P}$ terhadap tanaman adalah sebagai zat penbangun dan terikat dalam senyawa-senyawa organis. Dengan demikian statis, hanya sebagian kecil saja sesungguhnya yang terdapat dalam bentuk anorganis sebagai ion-ion fosfat, sebagai bahan pembentuk fosfor terpencar-pencar dalam tubuh tanaman semua inti mengandung fosfor dan selanjutnya sebagai senyawa-senyawa fosfat di dalam sitoplasma dan memberan sel. Bagian-bagian tubuh tanaman yang bersangkutan dengan pembiakan generatif, seperti daun-daun bunga, tangkai-tangkai sari, kepala-kepala sari, butir-butir tepung sari, daun buah serta bakal biji ternyata mengandung $\mathrm{P}$ jadi bagian maksud mendorong pembentukan bunga dan buah sangat banyak di perlukan unsur $\mathrm{P}$ (Nurhayati, 1986).

\section{Panjang Buah Pertanaman}

Berdasarkan hasil analisis ragam peubah data yang diamati, pemberian pupuk guano berpengaruh nyata terhadap panjang buah pertanaman. Hal ini menunjukkan bahwa pupuk guano yang diberikan pada tanah masih menyediakan unsur hara yang cukup bagi tanaman. Dalam hal ini, unsur K sangat dibutuhkan karena berfungsi untuk memproduksi karbohidrat dalam jumlah banyak, didukung oleh unsur $\mathrm{P}$ yang juga mencukupi kebutuhan hara tanaman untuk perkembangan bentuk buah (Novizan, 2002).

Unsur $\mathrm{K}$ berperan dalam memperluas pertumbuhan akar tanaman, sehingga tanaman dapat menyerap unsur hara dalam tanah lebih banyak. Selain itu, unsur K juga berperan dalam proses metabolisme, seperti fotosíntesis dan respirasi, dalam proses fotosíntesis unsur $\mathrm{K}$ berperan membantu proses membuka dan menutup stomata, sehingga proses fotosíntesis dapat berjalan dengan lancar. Hasil fotosintesis seperti karbohidrat dan gula ditranslokasikan pada pembentukan pati dan protein. Sehingga dengan adanya unsur $\mathrm{K}$ yang mencukupi kebutuhan hara tanaman pada masa ini menjadikan ukuran buah menjadi lebih besar. 
Hal ini juga didukung oleh ketersediaan unsur $\mathrm{N}$ dan $\mathrm{P}$ dalam tanah yang mencukupi, karena senyawa klorofil yang digunakan pada proses fotosíntesis dibentuk oleh unsur N. Sedangkan unsur $P$ dalam hal ini juga ikut berperan dalam perkembangan bentuk buah (Novizan, 2002).

\section{KESIMPULAN}

Adanya respon pertumbuhan dan hasil tanaman mentimun terhadap pemberian pupuk organik guano pada lahan rawa lebak dengan dosis terbaik adalah 10 ton.ha ${ }^{-1}$ setara dengan $1 \mathrm{~kg} \cdot$ petak $^{-1}\left(\mathrm{~g}_{2}\right)$.

\section{DAFTAR PUSTAKA}

BPS HSU. 2010. HSU Dalam Angka 2010. Badan Pusat Statistik Kab. HSU. Amuntai.

Cahyono, B. 2003. Timun. Aneka Ilmu. Semarang.

Hanafiah, K.A. 2002. Rancangan Percobaan. Rajawali Pers. Palembang.

Hariswanoso, 2011. Budidaya dan Analisa Usahatani Mentimun. http//hariswasono.blog.com.

Diakses Pada Tanggal 24 Maret 2012.

Isrun. 2006. Tanggap inceptisols terhadap pupuk guano dan pupuk $P$ serta pengaruhnya terhadap serapan $P$ tanaman jagung ( Zea mays var. Saccarata sturt ). J. Agrisains 7 (2).

Isrun. 2010. Perubahan serapan nitrogen tanaman jagung dan kadar Al-dd akibat pemberian kompos tanaman legum dan nonlegum pada inseptisols Napu. J. Agroland 17 (1).

Kaya, E. 2009. Ketersediaan fosfat, serapan fosfat, dan hasil tanaman jagung (Zea mays L.) akibat pemberian bokashi ela sagu dengan pupuk fosfat pada ultisols. J. Ilmu Tanah dan Lingkungan 9 (1).

Laboratorium Kimia, Fisika, Biologi Tanah Fakultas Pertanian Universitas Lambung Mangkurat . 2012. Hasil analisis tanah dan pupuk. Banjarbaru.

Mardalena. 2007. Respon pertumbuhan dan produksi tanaman mentimun (Cucumis sativus L.) terhadap urine sapi yang telah mengalami perbedaan lama fermentasi. Departemen Budidaya Pertanian. Fakultas Pertanian Universitas Sumatra Utara. Medan.

Mulyani. 2002, Peranan Pupuk Fosfor Terhadap Tanaman Sayuran Sinar Baru Agesindo. Bandung.

Marsono. 2007. Serapan Unsur Kalium di Dalam Tanah, Depok Estate.

Nurhayati. 1986. Pranan Pupukfosfor Untuk Tanaman Semusim. PT. Argo Media Pustaka. Depok Estate.

Novizan. 2002. Petunjuk Pemupukan Efektif. Agromedia. Jakarta.

Purwadi, E. 2011. Batas Kritis Suatu Unsur Hara (N) dan Pengukuran Kandungan Klorofil pada Tanaman. http://masbied.com. Diakses tanggal 26 Desember 2011.

Rafieq, A. 2004. Sosial Budaya dan Teknologi Kearifan Lokal Masyarakat dalam Pengembangan Pertanian Lahan Lebak di Kalimantan Selatan. Balai Pengkajian dan Pengembangan Teknologi Pertanian Kalimantan Selatan. Banjarbaru.

Rosmarkam, A. dan Nasih Widya Yuwono. 2002. Ilmu Kesuburan Tanah. Kanisius. Yogyakarta. 
Rukmana, R. 1994. Budidaya Mentimun. Kanisius. Yogyakarta.

Simatupang, R. S., Mawardi., E. Maftu'ah., dan S. Raihan. 2006. Tanggap hasil varietas mentimun terhadap pemakaiaan pupuk organik dilahan rawa lebak. Prosiding Seminar Nasional Pengelolaan Lahan Terpadu. Balai Besar Penelitian dan Pengembangan Sumberdaya Lahan Pertanian, Balai Penelitian Pertanian Lahan Rawa. Banjarbaru. ISBN :979-8253-60-4.

Sumpena. 2001. Budidaya Mentimun. Penebar Swadaya. Jakarta.

Suwarno dan Idris. K. 2007. Potensi dan kemungkinan penggunaan guano secara langsung sebagai pupuk di indonesia. J. Tanah dan Lingkungan 9 (1).

Utami, Sri Nuryani H, dan Suci Handayani. 2003. Sifat kimia entisol pada sistem pertanian organik. Ilmu Pertanian 10 (2).

Veanty, O. 2011. Daur/ Siklus fosfor. Http://kamuspengetahuan.blogspo t.com. Diakses tanggal 11 Februari 2012.

Winawanti, N. 2011. Tugas tanah http:blog.ub.ac.id.com. Diakses tanggal 21 Oktober 2013. 